\title{
Toxic effect of the marine dinoflagellate Gymnodinium galatheanum on juvenile cod Gadus morhua
}

\author{
Marianne V. Nielsen \\ Trondheim Biological Station, University of Trondheim, N-7004 Trondheim, Norway
}

\begin{abstract}
Juvenile cod Gadus morhua exposed to the dinoflagellate Gymnodinium galatheanum Braarud died within $2 \mathrm{~d}$; before death the fish became lethargic and affected fish showed increased plasma osmolality. Severe histopathological changes were found in the gill tissue, with extensive separation of the respiratory epithelium from the underlying pillar cells. Though no recent blooms have been recorded, G. galatheanum should be considered as a potentially harmful bloom-forming alga in temperate waters.
\end{abstract}

\section{INTRODUCTION}

The dinoflagellate Gymnodinium galatheanum Braarud was first described occurring in a bloom in 1950 in Walvis Bay, Southwest Africa (Braarud 1957). Observations from this bloom indicated that the alga was ichthyotoxic (Steemann Nielsen 1953). No other blooms of this alga have been recorded in the literature, but it is occasionally found in the North Sea region as an accompanying species in blooms of the toxic dinoflagellate Gyrodinium aureolum (Larsen \& Moestrup 1989). Gymnodinium galatheanum in culture has been shown to be toxic to mussels (Nielsen \& Strømgren 1991). G. galatheanum grows over a wide temperature $\left(10\right.$ to $\left.24^{\circ} \mathrm{C}\right)$ and salinity range $(9$ to $34 \%$ S), with maximum growth rate occurring around $21{ }^{\circ} \mathrm{C}$ and $23 \% \mathrm{~S}$. Since growth rates of more than $50 \%$ of the maximum occur above $9^{\circ} \mathrm{C}(24 \% \mathrm{~S})$ (Nielsen unpubl.), G. galatheanum should be considered as a potentially harmful bloom-forming alga in European waters. The present study is an investigation of how $G$. galatheanum in culture affects the behaviour, blood plasma osmolality and gill histology of juvenile cod.

\section{MATERIAL AND METHODS}

The Gymnodinium galatheanum culture used in this study was isolated from Oslofjord in 1976 by Karl Tangen. The algae were grown in $100 \mathrm{l}$ translucent polyethylene containers of filtered seawater (cartridge filter with a pore size about $0.1 \mu \mathrm{m}$ ), enriched to give the f/2 medium (Guillard \& Ryther 1962); the temperature was $15^{\circ} \mathrm{C}$, and the salinity was $34 \%$. Light was supplied from the side of the containers by banks of fluorescent tubes (Phillips TL 40W/55 de luxe). Irradiance (QSL-100 photometer, Biospherical Instruments, Inc.) was about $100 \mu \mathrm{mol} \mathrm{m} \mathrm{m}^{-2} \mathrm{~s}^{-1}$ in the middle of the growth containers. Daylength was $18 \mathrm{~h}$. The cultures used for exposure experiments were in the late exponential phase of growth. The cell density was determined by counting the algal cells in a Nageotte slide. Before exposure, dissolved inorganic phosphorus was measured in the culture medium (Koroleff 1976) and the $\mathrm{pH}$ of the culture was adjusted with $1 \mathrm{~N} \mathrm{HCl}$ to between 7.8 and 8.2.

One- to two-year-old cod Gadus morhua (length range: 20 to $24 \mathrm{~cm}$, weight range: 100 to $130 \mathrm{~g}$ ) in 
groups of 5 were exposed to 70 l batches of Gymnodinium galatheanum cultures of cell density $115 \times$ $10^{6}$ cells $1^{-1}$. Control groups ( 5 fish) were kept in batches of seawater. The batches were continuously aerated and the algal cultures/seawater renewed every $24 h_{i}$ the experimental temperature was maintained between 7 and $9^{\circ} \mathrm{C}$. Ammonia and $\mathrm{pH}$ were measured every day at the start and end of the exposures. Ammonia was analysed by the indophenol method according to Norwegian Standard NS 4746 (Anonymous 1975). The oxygen tension was measured frequently during the day with an oximeter (WTW Oxi 191).

Exposure time was $2 \mathrm{~d}$ for the control group fish. For the experimental group fish, exposure time was less than $2 \mathrm{~d}$ because fish were sampled for analysis when dead (first experiment) or dying (second experiment). Both groups were observed at 3 to $6 \mathrm{~h}$ intervals. Two independent experiments were performed.

Changes in behaviour, blood plasma osmolality, mortality and in the second experiment also changes in gill histology were studied to determine the effects the algae had on the fish. Blood samples were drawn by heart puncture into heparinized syringes, the plasma isolated by centrifugation $(10000 \times g, 5 \mathrm{~min})$ and its osmolality was determined with a Knauer osmometer using $50 \mu \mathrm{l}$ samples. Gill arches were fixed in phosphate-buffered formaldehyde and the gill filaments prepared for microscopy by standard histological techniques (haematoxylin-eosin staining).

Preliminary experiments showed that 1 - to 2 -yr-old cod can be kept in $70 \mathrm{l}$ batches of seawater, $\mathrm{f} / 2$ medium or cultures of a non-toxic alga (Isochrysis galbana, $280 \times 10^{6}$ cells $1^{-1}$ ) up to $4 \mathrm{~d}$ with no effects on the behaviour or on the plasma osmolality (range: 321 to $338 \mathrm{mOsm}$ ).

\section{RESULTS}

The Gymnodinium galatheanum cultures appeared healthy during the $24 \mathrm{~h}$ exposure experiments as they remained homogeneously distributed with no clogging and no settlement at the bottom of the experimental containers. The cultures were not phosphorus limited (Table 1) or nitrogen limited (the G. galatheanum con- tains relatively more phosphorus to nitrogen than does the $\mathrm{f} / 2$ medium: atomic $\mathrm{N} / \mathrm{P}$ ratio in $\mathrm{f} / 2$ medium $=24$; $N / P$ ratio in $G$. galatheanum cells $=7$ to $10 ; \mathrm{K}$. Hegge unpubl.).

Upon exposure, the fish in the experimental group appeared to stay close to the surface, often with their heads out of the water. This behaviour was different from that of the control group where the fish distributed themselves more uniformly in the experimental container.

In the first experiment, all the fish in the group exposed to Gymnodinium galatheanum died within the first $2 \mathrm{~d}$ of exposure. When the behaviour of the fish became abnormal (no swimming activity), they showed no muscular activity when lifted out of the water. At this stage of lethargy death occurred within $2 \mathrm{~h}$. Blood samples were drawn from the dead fish. Dead fish had distended gills and their mouths were wide open; in one case mucus was found on the gills of a dead fish. In the second experiment, blood and gill samples were taken from fish at the stage of lethargy described above. Since there was no significant difference in blood plasma osmolality between dead and lethargic fish, the data sets have been combined (Table 1). Blood samples from lethargic fish or fish just dead had a significantly higher mean plasma osmolality $(p<$ 0.001 ) than did blood samples from the control group (Table 1). The fish in the control group had normal blood plasma osmolality after $2 \mathrm{~d}$ of exposure.

Histological examination of formaldehyde-fixed gill filaments from 5 fish at the stage of lethargy described above, after exposure to Gymnodinium galatheanum for less than $2 \mathrm{~d}$, showed extensive separation of the respiratory epithelium from the underlying pillar cells (Fig. 1). At some locations the changes were greatest at the bases of the secondary lamellae, while at other lo-

Fig. 1 Gadus morhua exposed to Gymnodinium galatheanum. Section of gill held for 2 d in control medium (seawater) (upper panel) and after exposure $(<2$ d) to algal culture (lower panel). Representatives of 3 fish from the control group and 5 fish from the experimental group, $400 \times$. Photo by T T Poppe 


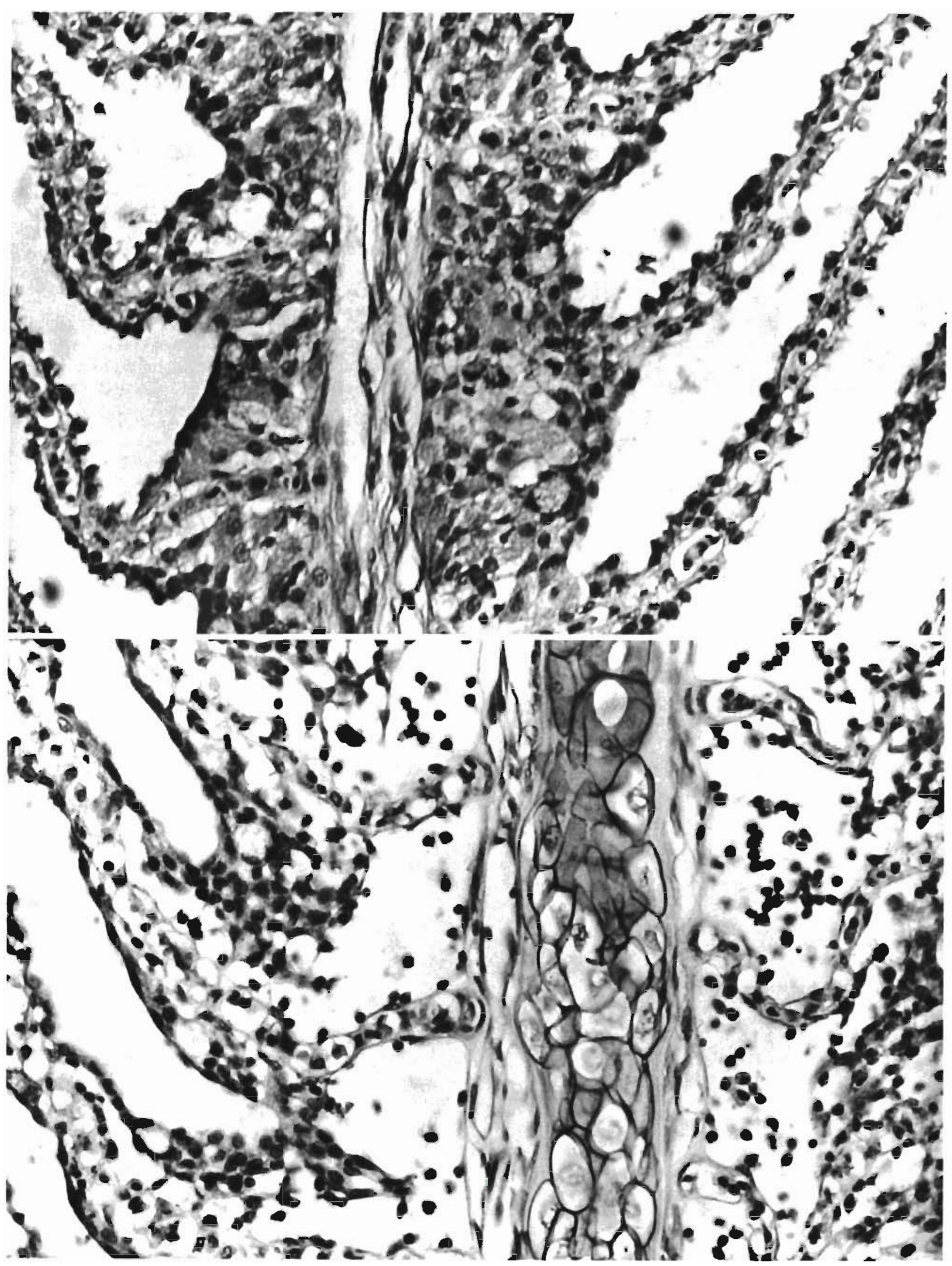


cations the largest changes were found more distally on the secondary lamellae. In the control group ( 3 fish), only locally moderate hypertrophic and hyperplastic changes appeared (Fig. 1).

During the experiment the $\mathrm{pH}$ remained between 7.5 and 8.1 and the oxygen tension was close to saturation.

\section{DISCUSSION}

Since the observations from the Danish Galathea Expedition in 1950 (Steemann Nielsen 1953), no other scientific reports have been published on the ichthyotoxic effects of the dinoflagellate Gymnodinium galatheanum. Toxic effects, however, have been shown for mussels (Mytilus edulis), where $24 \mathrm{~h}$ exposure to cultures of $G$. galatheanum gave significant decreases in shell-length growth (Nielsen \& Strømgren 1991). For mussels, significant toxic effects were found at cell densities above ca $120 \times 10^{6}$ cells $\mathrm{l}^{-1}$. In this experiment with juvenile cod a significant toxic effect was found at ca $115 \times 10^{6}$ cells $\mathrm{I}^{-1}$, the only cell density used.

The severe histopathological changes observed in the gill tissue from the experimental group exposed to Gymnodinium galatheanum are probably a result of toxin action. The closely related toxic alga Gyrodinium aureolum caused histological effects on the gills of Salmo salar (Jones et al. 1982) and Oncorhynchus mykiss (Roberts et al. 1983). These effects included a generalized necrotizing degeneration of the secondary lamellae accompanied by swelling and pyknosis of the primary lamellar epithelium and congestion of branchial vessels. This suggests that asphyxiation is the cause of death after exposure to both $G$. aureolum and Gymnodinium galatheanum.

In the control group, locally moderate hypertrophic and hyperplastic modifications appeared. Elevated ammonia levels in the surrounding medium may cause histological changes in the gill tissues of fish. During the experiments, ammonia accumulated through excretion from the fish. The $24 \mathrm{~h}$ ammonia accumulation for the control group $(99 \mu \mathrm{M})$ was far above that experienced by the experimental group fish (18 $\mu \mathrm{M}$ ) (Table 1), where the ammonia concentration may have been reduced by uptake of $\mathrm{NH}_{3}$ by Gymnodinium galatheanum cells. The minor histological modifications in gill tissue found in the control group fish were similar to those described by Ervik et al. (1987) for Salmo salar chronically exposed to 10 to $45 \mu \mathrm{M}$ ammonia $<147 \mathrm{~d}$, 8 to $10^{\circ} \mathrm{C}$, pH 7.7 to 8.2 ), and may be explained by a high ammonia load.

The fish showed an increased plasma osmolality after exposure to Gymnodinium galatheanum. A simi- lar effect on the plasma chloride has been found when exposing Atlantic salmon Salmo salar and rainbow trout Oncorhynchus mykiss to the toxic alga Chrysochromulina polylepis (Leivestad \& Serigstad 1988). The toxins from $C$. polylepis probably increased the permeability of the fish gill (Leivestad \& Serigstad 1988). The observations of the gill histopathology in the current study may result from increased permeability causing oedema which again could explain the separation of the respiratory epithelium.

In aquaculture, knowledge of the threshold for effects of toxic algae in terms of algal cell density (critical concentrations) would be very useful to guide the development of measures to cope with blooms of toxic algae. Recent results have shown, however, that the toxin production of algae may not be constant, but varies with the growth conditions of the algae (Boyer et al. 1987, Edvardsen et al. 1990). The variability in toxin production implies that it is impossible to determine the threshold for effects of toxic algae in terms of algal cell densities.

Acknowledgements. Thanks are due to Professor T. T. Poppe, National Veterinary Institute, Oslo, Norway, for gill preparations and interpretation of the histological changes.

\section{LITERATURE CITED}

Anonymous (1975). Determination of ammonia-nitrogen. Norwegian Standard NS 4746. Norges Standardiseringsforbund, 0306 Oslo 3, Norway

Boyer, G. L., Sullivan, J. J., Andersen, R. J., Harrison, P. J., Taylor, F. J. R. (1987). Effects of nutrient limitation on toxin production and composition in the marine dinoflagellate Protogonyaulax tamarensis. Mar. Biol. 96: 123-128

Braarud, T. (1957). A red water organism from Walvis Bay. Galathea Rep. 1: 137-138

Edvardsen, B., Moy, F., Paasche, E. (1990). Hemolytic activity in extracts of Chrysochromulina polylepis grown at different levels of selenite and phosphate. In: Granéli, E., Sundström, B., Edler, L., Anderson, D. M. (eds.) Toxic marine phytoplankton. Proc. Fourth Int. Conf. on Toxic Marine Phytoplankton, June 26-30, Lund, Sweden. Elsevier, New York, p. 284-289

Ervik, A., Ellingsen, H.-M., Farestveit, E., Floysand, R. Ulriksen, D., Waagbo, R. (1987). The effect of chronic ammonia exposure on growth, gill structure, blood chemistry and catecholamines on Atlantic salmon (Salmo salar). Comm. Meet. Int. Com. Explor. Sea CM-ICES/F: 39

Guillard, R. R. L., Ryther, J. H. (1962). Studies on marine planktonic diatoms I. Cyclotella nana Hustedt and Detonula confervacea (Cleve) Gran. Can. J. Microbiol. 8: $229-239$

Jones, K. J., Ayres, P., Bullock, A. M., Roberts, R. J., Tett, P. (1982). A red tide of Gyrodinium aureolum in sea lochs of the Firth of Clyde and associated mortality of pond-reared salmon. J. mar. biol. Ass. U.K. 62: 771-782

Koroleff, F. (1976). Determination of phosphorus. In: Grasshoff, K. (ed.) Methods of seawater analysis. Verlag Chemie, Weinheim, p. 117-126 
Larsen, J., Moestrup, $\oslash$. (1989). Guide to toxic and potentially toxic marine algae. Institut for Sporeplanter, University of Copenhagen. Fish Inspection Service, Ministry of Fisheries, Copenhagen, Denmark, p. 33-36

Leivestad, H., Serigstad, B. (1988). Some observations on the effects of Chrysochromulina polylepis on the osmoregulation in fish. Rapport/Notat Nr. BKO 8803. Havforskningsinstituttet, Bergen, Norway

Nielsen, M. V., Strømgren, $T$ (1991). Shell growth response of

This article was presented by H. R. Skjoldal, Bergen, Norway mussels (Mytilus edulis) exposed to toxic microalgae. Mar Biol. 108: 263-267

Roberts, R. J., Bullock, A. M., Turner, M., Jones, K., Tett, P. (1983). Mortality of Salmo gairdneri exposed to cultures of Gyrodinium aureolum. J. Mar Biol. Ass. U.K. 63: 741-743 Steemann Nielsen, E. (1953). Måling af havets stofproduktion. In: Bruun, A. F., Greve, Sv., Mielche, H., Spärck, R (eds.) Galatheas jordomsejling 1950-1952. Schultz Forlag, Kobenhavn, p. 65-76

Manuscript first received: December 3, 1991 Revised version accepted: February 4, 1993 